\title{
キュウリピクルスのテクスチャーとペクチン組成に 及ぼす無機成分の影響
}

\author{
桑原祐二*・大塚暢 幸*・真部正敏**
}

\section{Effect of Minerals on Texture and Pectin Components of Cucumber Pickles}

\author{
Yuji Kuwahara*, Nobuyuki Otsuka* and Masatoshi Manabe** \\ * Department of Food Science, Matsuyama Shinonome Junior College, \\ Kuwabara-cho, Matsuyama-shi, Ehime, 790 \\ ** Department of Food Science, Faculty of Agriculture, Kagawa \\ University, Miki-cho, Kida-gun, Kagawa, 761-o7
}

In order to improve the texture of cucumber pickles, the effect of minerals $(\mathrm{K}, \mathrm{Ca}, \mathrm{Mg}, \mathrm{Al}$ ) on the firmness was studied by analyzing the characteristic properties of pectin components of cucumber pickles, and the results were obtained as follows: (1) On calcium chloride treatment, the firmness increased with the increasing amount of $\mathrm{Ca}$ added. Using calcium chloride with potassium chloride, as well as calcium chloride with magnesium chloride, little change was found in the firmness as compared with the use of calcium chloride alone at the same level as $\mathrm{Ca}$ content. Aluminum ion might restrain the texture firming effect of calcium chloride when used with calcium chloride. (2) The Ca content in alcohol insoluble substance (AIS) increased with the increase of $\mathrm{Ca}$ concentration used for the treatment. When potassium chloride or magnesium chloride was used with calcium chloride, almost the same Ca content in AIS was found as that treated with calcium chloride alone at the same Ca-level. The addition of aluminum chloride distinclly decreased it. (3) On the pectin composition of AIS, the water soluble pectin and the hydrochloric acid soluble pectin were always found to be in a smaller amount than other pectin fractions. Hexametaphosphate soluble pectin fraction (PSP) was found more abundantly in all treated samples, especially when used calcium chloride with aluminum chloride. The sodium hydroxide soluble pectin fraction was remakably decreased than PSP after aluminum chloride treatments, while it obviously remained higher in other treatments.

(Received Dec. 3, 1984)

キュウリピクルスは食生活の多様化および最近の健康 上の理由による低塩化嗜好とすあいまって，消費量はし だい增加の㑯向を示してきている。わが国のピクルス 用原料忹内生産量が少なく，その多くは米国，スペイ ン等から塩蔵キュウリを輸入しているのが実情である。 ピクルスの商品的価値は塩蔵キュウリの品質により大き く左右されるため, 加工用原料は十分吟味しておく必要 があるが，斉一な輸入塩蔵品を得ることは，キェウリの 品種, 塩蔵の方法や保存期間等が異なるため, 現実には
困難な問題といえる。従って，ピクルスの商品性を損ら ことなく、テクスチャーを改善する方法が求められてい るが，問題解決にはいたっていない。

漬物類のテクスチャーは青果物の組織を構成するペク チン質, へミセルロースやセルロースといった多梼成分 に影響されるところが大きい。キュウリピクルスのテク スチャーは，一般の浿物のクリスブ性とは若干異なって いるとはいえ"，組䄉を構成する成分が両者で異なるよ らには思われない。キュウリピクルスのテクスチャーを

* 松山東嘿短期大学食物科（广 790 松山市桑原町）

* 香川大学㕮学部食品学科（广 761-07 香川装木田郡三木町） 
把握するには，組織成分を詳細に検討する必要があるが， 今回はテクスチャーに及ぼす無機成分の影袒をみること にした。

一般に, 園芸食品のテクスチャャ一改善のために, カルシ ウム塩等の添加が試みられている。少これは主に組織内 のペクチン酸やペクチニン酸のカルボキシル基 $(\mathrm{COOH})$ とカルシウムイオンとの間での架橋の形成によるものと 考えられている。キュウリピクルスについてるカルシウ ム塩を添加してテクスチャ一を改善している報告引がみ られる。しかしながら，カルシウム塩と同様にテクスチ ャ一政善のために添加が試みられているアルミニウム 塩"等の他の無機成分とカルシウム塩とを併用した場合 のテクスチャー, ペクチン及び無機成分の挙動について は明らかにされていない。

本報告はキュウリピクルスに上記のカルシウム塩の み（カルシウム単用と略す）を添加した場合，カルシウ ム塩にフルミニウム塩を併用添加した場合，さらに食塩 のにがり成分としてテクスチャーにも関与すると考えら れているマグネシウム塩”，また参考としてナトリウム と同じ原子価のカリウム塩をカルシウム塩に併用添加し た昜合，それらがキュウリピクルスのテクスチャー， ペ クチン及び無機成分の挙動にいかなる影響を及ほすかに つて調べたるのである。

\section{実 験 方 法}

\section{1. 試料}

キュウリは香川県大川郡長尾町の農家で栽培されたピ クルス用品種 Wisconsin SMR 13 を供試した。

キニウリは一果平均重量 $24 \mathrm{~g}$, 大きさは $7.5 \times 2.5 \mathrm{~cm}$ のbのを用い，原料に対して食塩（試薬一級・塩化ナト リウム）を $20 \%$ 加光，水揚り徙，発醖を防止するため トルエンを加えて落し蓋をし，厚手のポリエチレン布で 密封した。約 2 カ月間室温 $\left(15 \sim 25^{\circ} \mathrm{C}\right)$ に放固した。こ の塩蔵キュウリを約 2 日間水浸漬して食塩瀑度を的 $2 \%$ に下げて，切断せず，そのまま $450 \mathrm{ml}$ 容瓶容器に $270 \mathrm{~g}$ (平均11本) 肉詰した。

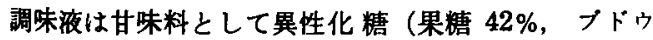
結 $50 \%$ 含有)を，酸味料としては試薬一級の酶酸，リン コ酸、クェン酸を用いた。また，これに食塩を加えた。

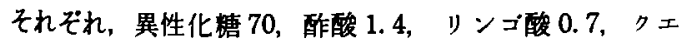
酸 0.7 ，食塩 2.2 ，水 25 の配合割合で調製した。この 調味液は $\mathrm{pH} 1.9,48^{\circ} \mathrm{Bx}$ であり,このものを先の容器 K $210 \mathrm{~g}$ 注入した。カルシウム等の塩類は調味液に溶解 して添加した。
ピクルスと調味液を入れた容器は密封後, $75^{\circ} \mathrm{C}, 30$ 分 間殺菌した。それを室温で保存し，製造6 月月目に試験 に供した。

添加する無㙨成分としては，試薬一級の塩化カルシウ 厶 $\left(\mathrm{CaCl}_{2} \cdot 2 \mathrm{H}_{2} \mathrm{O}\right.$ カルシウムと略称), 塩化カリウム ( $\mathrm{KCl}$ カリウムと略称), 塩化マグネシウム $\left(\mathrm{MgCl}_{2} \cdot\right.$ $6 \mathrm{H}_{2} \mathrm{O}$ マグネシウムと略称), 塩化アルミニウム $\left(\mathrm{AlCl}_{8}\right.$ $6 \mathrm{H}_{2} \mathrm{O}$ フルミニウムと略称) の各塩類を使用した。各塩 類の添加量は瓶詰の内容総量 $100 \mathrm{~g}$ に対する無機成分 (カチオン) の含量で示した。カルシウム単用区の添加 量は $20,50,100 \mathrm{mg}$ とした。また，カルシウムと他の 無機成分との併用試験では，それぞれの添加量を20 と $20 \mathrm{mg}, 20$ と $40 \mathrm{mg}, 40$ と20 mg の混合比とした。

\section{2. 硬度の測定}

果肉硬度については，Fig. 1に示すように，果皮をつ けたままで矢印の方向にプランジャーを侵入させて，そ の最大荷重を測定する方法とキュウリピクルスを輪切 りにして，その切断面に対して直角にプランジャーを侵 入させて，その最大荷重を測定する方法で検討した。前 者は果皮の破断時に最大荷重を示すのに対して, 後者の それは果肉侵入時の最大荷重を示しており，内容的には 異なる ののの，相方の 測定結果は極めて相関関俰が高 く，従って，今回は果皮をつけたままで，Fig. 1に示す 前者の方法で, 試料の 3 部位について測定した。測定は FUDOH Rheometer を用い,レンシ $200 \mathrm{mV}$ ，テーブ ルスピード $5 \mathrm{~cm} / \mathrm{min}$, プランジ+ーは $3 \mathrm{~mm} \phi$ 針入弹 性用によった。硬度はプランジャーが表皮下約 $6 \mathrm{~mm} に$ 達するまで侵入させ，果皮破断時の最大荷重をそれぞれ の部位につき 35 個体測定し平均值を求め，それぞれの 記号で図示した。硬度の値は記録計のチャート紙のピー クの高さから荷重值を計算し，プランシャーの断面積で 割って $\mathrm{g} / \mathrm{mm}^{2}$ で表わした。

\section{3. アルコール不溶性固形物の調製}

キュゥリピクルスは，へた部，中央部，花落部に 3 等

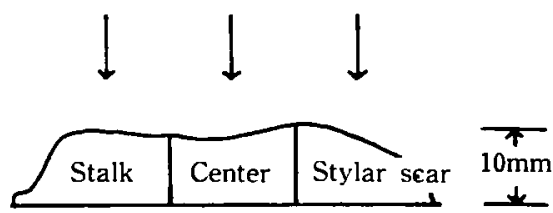

Fig. 1 The position used for preparation of the alcohol insoluble substance from cucumber pickles and the direction of penetration for measuring the firmness of them 
分し，それぞれ約 $200 \mathrm{~g}$ に $99 \%$ エタノールを 2.5 倍量 加えて，オスター製の家庭用高速ミキサーで 2 分間磨研 したのち，5分間沸騰加熱処理をした。フェノール硫酸 反応で榶の反応が陰性になるまで70\%エタノールでく

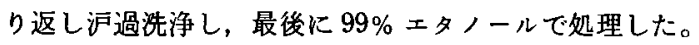
これを $40^{\circ} \mathrm{C}$ で減圧乾燥し，さらに日本理化学器機 (株) 䡈の分析粉砕器 R-8 型を使用して改粉末にし, アルコ ール不溶性固形物（AIS と略す）を調製した。

\section{4. 無機成分}

カリウム, カルシウムおよびマグネシウムは試料の AIS に硝酸-過塩素酸の 混液を加えて湿式分解を行な い, Nippon Jarrell Ash 社製原子吸光炎光共用分光分 析装固 AA 782 型を用いて原子吸光法6)により定量し た。カルシウムは干涉除去剤としてストロンチウムを添 加して測定した。フルミニゥムはフルミノンによる比色 法りで剆定した。

\section{5. ペクチンの抽出と定量}

AIS $1.0 \mathrm{~g}$ を $300 \mathrm{~m} l$ 容三角フラスコに取り, $150 \mathrm{~m} l$ の水を加壳, $1 \mathrm{~m}$ の空冷管を付して $20^{\circ} \mathrm{C}, 12$ 時間抽出 したものを $250 \mathrm{~m} l$ 容のメスフラスコに移して定容とし， 東洋口紙 No. 2 で沪過した。この抽出液には水可溶性 ペクチン (WSP と略す) が含まれている。次に,この 残椬をフェノール硫酸反応がなくなるまで水で洗浄した ものに $4 \%$ \%キサィタリン酸ナトリウム溶液 $25 \mathrm{ml}$ を加 え, 全容を $250 \mathrm{~m} l$ とし， $20^{\circ} \mathrm{C}$ で 2 時間放置してへキサ メタリン酸可溶性ペクチン (PSP と略す) を抽出した。 以下，同様に水洗して，その残椬に $10 \mathrm{~m} l$ の $1 \mathrm{~N}$ 塩酸 溶液を加えて全容を $200 \mathrm{~g}$ とし，1時間募沸して塩酸可 溶性ペクチン（HSP と略す）を抽出した。最後に，前 回日本産と米国産のキュウリピクルスのペクチン量を比 較した際8，生のキュウリについては調べていないが， 一般に青果物では HSP の割合が高く9, それに比べて キュウリピクルスの HSP は著しく低いことに䇠念を抱 き，今回は以上の 3 画分のほかに水酸化ナトリウムによ る抽出を試みた。すなわち，HSP を抽出した残椬をつ エノール硫酸反応がなくなるまで洗浄し、これに $100 \mathrm{ml}$ の $0.05 \mathrm{~N}$ 水酸化ナトリゥム溶液を加之， $30^{\circ} \mathrm{C}, 2$ 時間 放嘈して水酸化ナトリウム可溶性ぺクチン（SSP と略

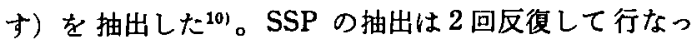
た。それぞれの抽出にあたり，時々振とらを行なった。 またそれぞれの抽出液について McCoмB の方法"11に準 じてカルパソール比色法で無水ガラクッロン酸含量を求 めた。またこれらの可溶性ぺクチンの和を総ペクチン とした。

\section{実験結果及び考察}

\section{1. 果肉硬度に及ぼす無機成分の影传}

硬度は Fig. 2 に示すごとく，カルシゥム単用区はい ずれの部位に拉いても対照区と比較して高い值を示し た。また, 添加量が増加するに伴って硬度は増大する傾 向がみられた。特に対照区に比べて，カルシウム $20 \mathrm{mg}$ 添加区において硬度の著しい増大が琶められた。しか し，20 mg 以上では添加量が增大しても硬度は少し高く なるにすぎず，大きな変化はみられなかった。また，そ れぞれの部位についてみると，へた部が最も高く，中央 部，花落部の順で硬度は低下した。

次にカルシウムーカリウム, カルシウムーマグネシウム の併用試験の結果を Fig. 3, Fig. 4 に示した。いずれ も対照区と比へてて添加区が硬度は增大している。しか L, Fig. 2 のカルシゥム単用区のむのに比べて, 併用 の効果はみられず，その值はほとんどカルシウム単用区 の場合と似通っていたが，カルシウムおよびマグネシウ ムの 添加比が 異なれば硬度に若干の変化が現われてい る。すなわち，カルシウムーカリウム併用区について，

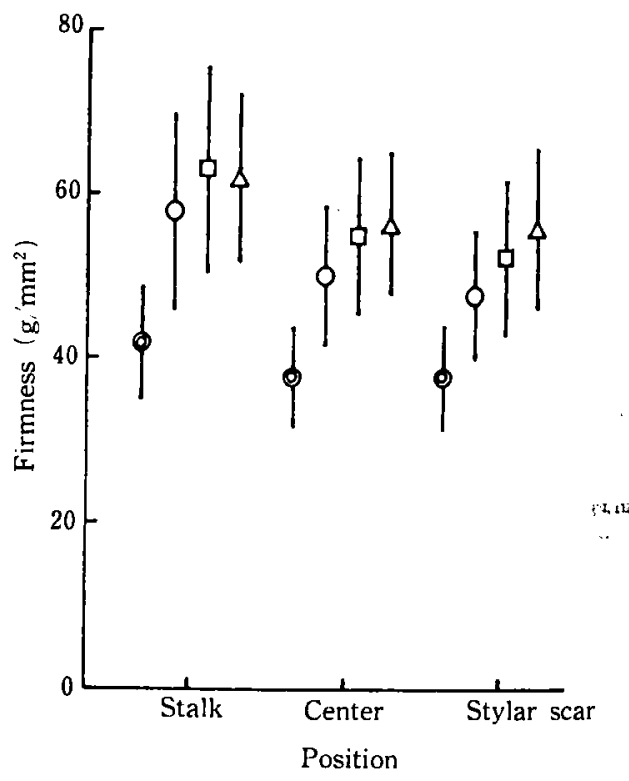

Fig. 2 Effect of calcium on firmness of cucumber pickles

๑: Control, O: $20 \mathrm{mg} \mathrm{Ca}$, 口: $50 \mathrm{mg} \mathrm{Ca}$ $\Delta: 100 \mathrm{mg} \mathrm{Ca}$

Each figure is the weight of calcium added per $100 \mathrm{~g}$ cucumber pickles tested. 


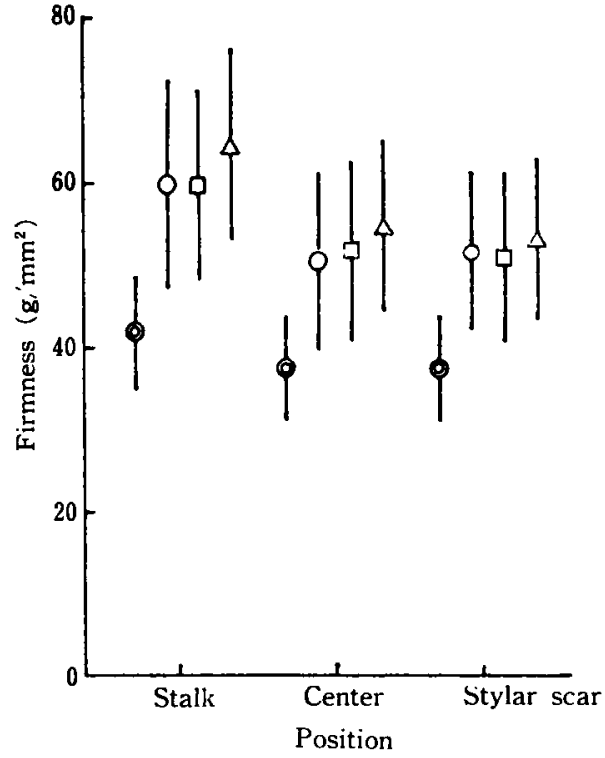

Fig. 3 Effect of calcium and potassium on firmness of cucumber pickles

: Control, O: $20 \mathrm{mg} \mathrm{Ca}$ and $20 \mathrm{mg} \mathrm{K}$

口: $20 \mathrm{mg} \mathrm{Ca}$ and $40 \mathrm{mg} \mathrm{K}$

$\Delta: 40 \mathrm{mg} \mathrm{Ca}$ and $20 \mathrm{mg} \mathrm{K}$

Each figure is the weight of calcium and potassium added per $100 \mathrm{~g}$ cucumber pickles tested.

等量またはカリウムをカルシウムの 2 倍量泒加した区で は，それぞれへた部 $59.4,59.5 \mathrm{~g} / \mathrm{mm}^{2}$, 中央部 50.4 ， $51.4 \mathrm{~g} / \mathrm{mm}^{2}$, 花落部 $51.3,50.7 \mathrm{~g} / \mathrm{mm}^{2}$ といずれの部 位に扎ててほぼ同し硬度を示した。これに対してカル シウムをカリウムの 2 倍量添加した区は，人た部 64.2 $\mathrm{g} / \mathrm{mm}^{2}$, 中央部 $54.4 \mathrm{~g} / \mathrm{mm}^{2}$, 花落部 $53.1 \mathrm{~g} / \mathrm{mm}^{2}$ であ ク，カルシウムの添加量の增加に伴って硬度む增大し た。一方，カルシウムーーグネシウム併用区については， 等量またはマタネシウムをカルシウムの 2 倍量添加した 区を比較してみると，それぞれ，へた部59.6，56.9 g/ $\mathrm{mm}^{2}$, 中央部 $50.4,47.9 \mathrm{~g} / \mathrm{mm}^{2}$, 花落部 $48.8,47.1$ $\mathrm{g} / \mathrm{mm}^{2}$ といずれの部位においても等量区の硬度が高い。 しかし, カルシウム $20 \mathrm{mg}$ 単用区とカルシウム $20 \mathrm{mg}-$ マタネシウム $20 \mathrm{mg}$ 併用区の硬度は，それぞれ，へた 部 $57.8,59.6 \mathrm{~g} / \mathrm{mm}^{2}$, 中央部 $50.0,50.4 \mathrm{~g} / \mathrm{mm}^{2}$, 花 落部 $51.3 ， 48.8 \mathrm{~g} / \mathrm{mm}^{2}$ とほとんど差が認められず，力 リウムを併用した場合と同様，マグネシウムの併用添加 も硬度に対する効果は認められないばかりか，返ってマ グネッムの添加量によっては硬度に低下の傾向がみら

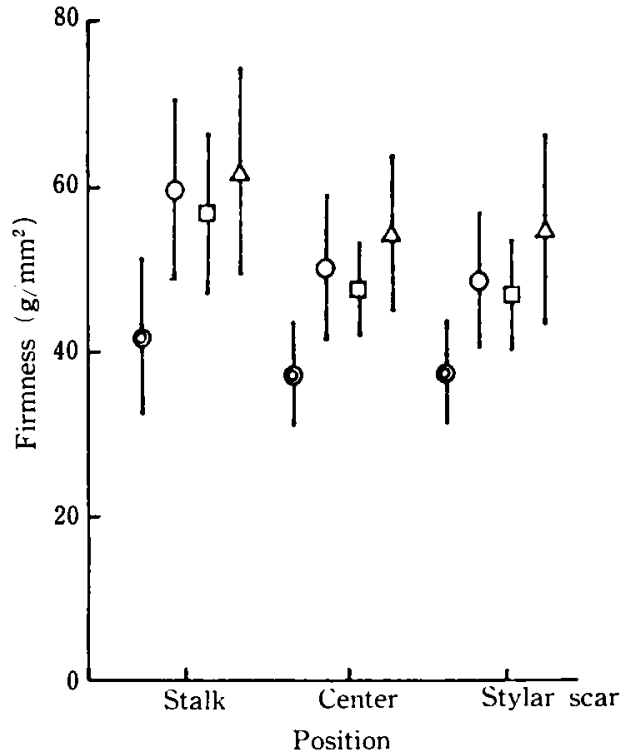

Fig. 4 Effect of calcium and magnesium on firmness of cucumber pickles

(O): Control, O: $20 \mathrm{mg} \mathrm{Ca}$ and $20 \mathrm{mg} \mathrm{Mg}$

ㅁ: $20 \mathrm{mg} \mathrm{Ca}$ and $40 \mathrm{mg} \mathrm{Mg}$

$\Delta: 40 \mathrm{mg} \mathrm{Ca}$ and $20 \mathrm{mg} \mathrm{Mg}$

Each figure is the weight of calcium and magnesium added per $100 \mathrm{~g}$ cucumber pickles tested.

れた。しかし，カルシウムがマグネシウムの 2 倍量添加 区では等量区よりも硬度は高くなり，カルシウムの添加 量の増加に伴って硬度の增大が認められた。

カルシゥムーアルミニゥム併用試験の結果はFig. 5 に 示す通りである。いずれの試験区においても添加区と対 照区の間で硬度の羑はほとんど認められなかった。アル ミニウムの 2 倍量のカルシウム添加でも硬度に変化が認 められないところから，アルミニウムはカルシウムの作 用を抑制しているよらに思われる。

フルミニウムは一般的にはミョウハンとして添加さ れ，例えば小梅溃などのテクスチャー改善に用いられて いる゙。しかし，本実験ではカルシウムとの併用ではあ るが，フルミニウムの効果は認められなかったので,こ の点については今後検討を行なら予定にしている。

\section{AIS 中の無識成分}

Fig. 6 にIS 中の 無機成分の 測定結果を示した。 AIS はピクルスの中央部のものを用いた。カルシウム 単用区では当然のことながらカルシゥム添加量の增加に 伴って AIS 中のカルシゥム含量は增加した。カルシウ 


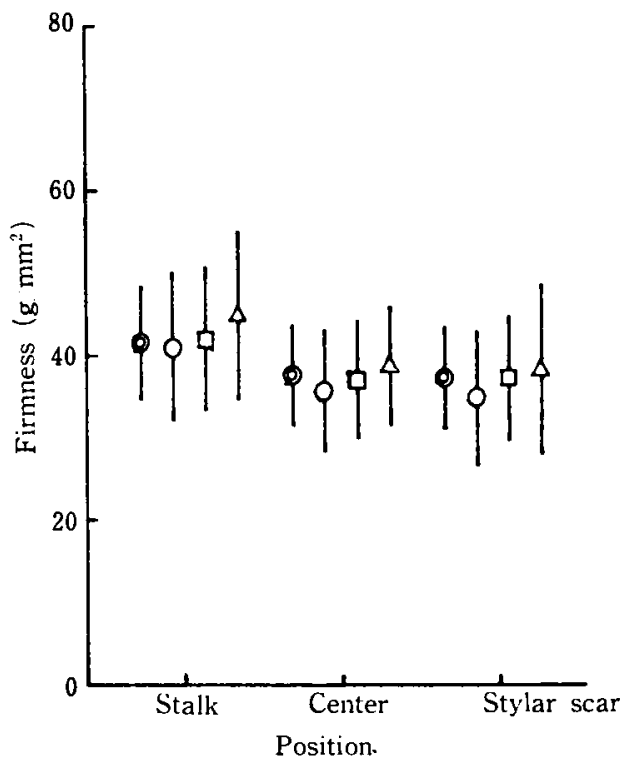

Fig. 5 Effect of calcium and aluminum on fir mness of cucumber pickles

(O): Control, O: $20 \mathrm{mg} \mathrm{Ca}$ and $20 \mathrm{mg} \mathrm{Al}$

ㅁ: $20 \mathrm{mg} \mathrm{Ca}$ and $40 \mathrm{mg} \mathrm{Al}$

$\Delta: 40 \mathrm{mg} \mathrm{Ca}$ and $20 \mathrm{mg} \mathrm{Al}$

Each figure is the weight of calcium and aluminum added per $100 \mathrm{~g}$ cucumber pickles tested.
ムーカリウム併用区においてて，カルシウム含量はカリウ ムの添加による影響はほとんど認められず，カルシウム 添加量に伴って增加した。しかし，カリウム含量はカル シウム $20 \mathrm{mg}$ にカリウム添加量が $20,40 \mathrm{mg}$ の区では $33 ， 54 \mathrm{mg} / 100 \mathrm{~g}$ と増加したが，カルシウムがカリウム の 2 倍量添加された区は $18 \mathrm{mg} / 100 \mathrm{~g}$ とカルシウムの添 加量の影慗が認められた。しかし，いずれにしてもカリ ウム含量はカルシウム含量に比べて極めて少量であっ た。これはカルシウムとカリウムのペクチンとの結合力 の差によるむのと考えられる。

次にカルシウムーマグネシウム併用区では, カルシウ ム含量はカルシウム添加量に伴って增加したが，カルシ ウム $20 \mathrm{mg}$ にマグネシウムを 20,40 mg 添加した区の カルシウム含量はそれぞれ 741，683 mg/100 g とマグ ネシウムの添加量の增加に伴ってカルシウムは減少を示 した。これはカリウム併用区の場合と異なるが，カリウ ムとマグネシウムにおけるペクチンとの結合力の差によ るものと考号れる。いずれにしてもカリウム、マグネ シウムに比較して，カルシウムの結合力がかなり強いこ とが認められる。

次にカルシウムーフルミニウム併用区では，他の併用 区と比ぺてカルシウム含量はいずれの区においてもかな りの減少が認められた。特にカルシウム $20 \mathrm{mg}$-アルミニ ウム $40 \mathrm{mg}$ 併用区でのカルシウム含量は $185 \mathrm{mg} / 100 \mathrm{~g}$ と対照区の $318 \mathrm{mg} / 100 \mathrm{~g}$ よりも低くなっている。一

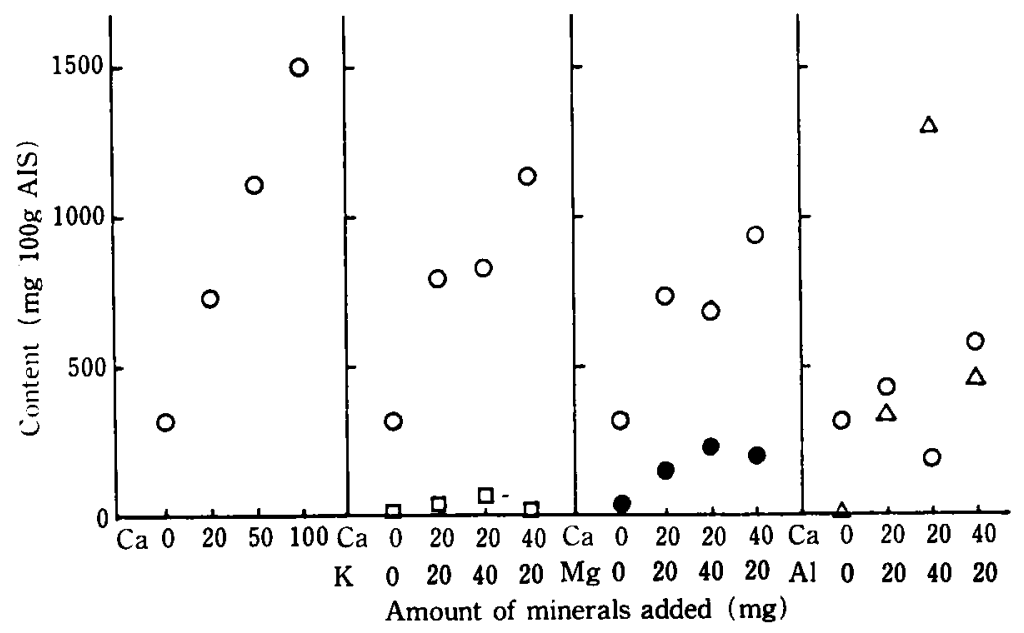

Fig. 6 Content of minerals in the alcohol insoluble substance prepared from the center of cucumber pickles

$\mathrm{O}: \mathrm{Ca}, \mathrm{\square}: \mathrm{K}, \bullet: \mathrm{Mg}, \Delta: \mathrm{Al}$

Each figure is the weight of minerals added per $100 \mathrm{~g}$ cucumber pickles tested. 
方、フルミニウム含量は $1148 \mathrm{mg} / 100 \mathrm{~g}$ と著しく高い 值を示した。また，カルシウムをてルミニウムの 2 倍量 加しても，他のカリウム扰よびマグネシウム併用区と 異なり，カルシウム含量はアルミニウム含量とほぼ同じ であった。これはアルミニウムの方がカルシウムに比べ てベクチンとの結合力が強く，従って，アルミニウムイ オンの增加に伴ってカルシゥムイオンとペクチンとの結 合が抑制されたためであろうと考えられる。

これらの無機成分の相互作用, 無機成分の組織への取 り込み方については明らかでなく，今啳检討する予定で ある。

\section{3. ペクチン含量の变化}

キュウリピクルスの部位ごとにペクチンを分画抽出し て調べたが，いずれの部位もほぼ同じ順向であったので ここでは中央部のみを取り上げ Table 1 に示した。

AIS 中のペクチン総量はほぼ 15～17\% であり，部位 や添加した無機成分の種類，濃度による差異はほとんど 認められなかった。WSP と HSP は他の可溶性ぺクチ ンに比へてて非常に少なく, WSP で約 $1.0 \sim 1.8 \%$, HSP は 1.4〜2.1\% であった。いずれの区もそれらのペクチ ン量は対照区に比へて，ほぼ同じか，若干減少している 程度であった。

一方, PSP とSSP は前述の可溶珄ぺクチンに比べて
かなり高く，特に SSP はアルミニウム泒加区を除けば 全ペクチンの約 $50 \%$ に達した。カルシウムーフルミニウ ム併用区での SSP は 1.7〜3.5\%と他の区の 7.0〜9.1\% に比べて著しく低い值を示したが，PSPはほぼと 反対の傾向を示し，なかでもアルミニウムをカルシウム の 2 倍量添加した区では PSP は対照区の約 2 倍であっ た。

全ペクチンに占める可溶性ペクチンの構成比を Fig. 7 に示した。この図からカルシウム単用区およびカルシウ ムーカリウム，カルシウムーマグネシウム併用区では無機 成分の種類, 添加濃度が異ってもぺクチンの構成比が大 きく異なるよらなことはなかった。

一般に青果物の組織内で遊離状態にある水溶性べクチ ンは肉質保持の機能を持たないが，カルシウム等の多価 陽イオンと結合している水不溶性の PSP H HSP はそ の機能を有するといわれている121。一方，カルシウムイ オンによる硬化状熊が野菜の種類で異なることから，カ ルシゥムが硬化の主要因とはなり得ないとする報告 ${ }^{13)}$ ある。

そこで,キュウリピクルスの硬度とペクチンとの関係 についてみると，対照区に比べて硬度が増大した区は，

Fig. 2，3，4 に示すよ5に，カルシウム単用区， カル シウムーカリウム拈よびカルシウムーマグネシウム併用区

Table 1 Content of pectins in the alcohol insoluble substance (AIS) prepared from the center of cucumber pickles after treating with various cations

\begin{tabular}{|c|c|c|c|c|c|}
\hline \multirow{2}{*}{ Treatment } & \multicolumn{5}{|c|}{ Pectin (g/100 g AIS) } \\
\hline & W S P & P S P & H S P & S S P & $\mathbf{T} \quad \mathbf{P}$ \\
\hline Control & 1.5 & 5.5 & 2.1 & 6.6 & 15.6 \\
\hline $20 \mathrm{mg} \mathrm{Ca}$ & 1.3 & 4.4 & 1.7 & 7.5 & 14.8 \\
\hline $50 \mathrm{mg} \mathrm{Ca}$ & 1.5 & 3.8 & 1.4 & 8.6 & 15.3 \\
\hline $100 \mathrm{mg} \mathrm{Ca}$ & 1.4 & 4.1 & 1.9 & 8.3 & 15. 6 \\
\hline $20 \mathrm{mg} \mathrm{Ca}$ and $20 \mathrm{mg} \mathrm{K}$ & 1.8 & 4.5 & 1.6 & 7.9 & 15.8 \\
\hline $20 \mathrm{mg} \mathrm{Ca}$ and $40 \mathrm{mg} \mathrm{K}$ & 1.6 & 4. 7 & 1.6 & 8.4 & 16. 2 \\
\hline $40 \mathrm{mg} \mathrm{Ca}$ and $20 \mathrm{mg} \mathrm{K}$ & 1.5 & 5.0 & 1.7 & 9.1 & 17.3 \\
\hline $20 \mathrm{mg} \mathrm{Ca}$ and $20 \mathrm{mg} \mathrm{Mg}$ & 1.8 & 5.0 & 1.5 & 7.0 & 15.3 \\
\hline $20 \mathrm{mg} \mathrm{Ca}$ ahd $40 \mathrm{mg} \mathrm{Mg}$ & 1.3 & 5.3 & 1.6 & 7.5 & 15.7 \\
\hline $40 \mathrm{mg} \mathrm{Ca}$ and $20 \mathrm{mg} \mathrm{Mg}$ & 1.2 & 4.6 & 1.7 & 7.6 & 15.0 \\
\hline $20 \mathrm{mg} \mathrm{Ca}$ and $20 \mathrm{mg} \mathrm{Al}$ & 1.2 & 8.4 & 2.1 & 3.5 & 15. 1 \\
\hline $20 \mathrm{mg} \mathrm{Ca}$ and $40 \mathrm{mg} \mathrm{Al}$ & 1.0 & 10.5 & 1.5 & 1.7 & 14.6 \\
\hline $40 \mathrm{mg} \mathrm{Ca}$ and $20 \mathrm{mg} \mathrm{Al}$ & 1.2 & 8. 3 & 1.9 & 3.3 & 14.7 \\
\hline
\end{tabular}

The amount of each mineral is the weight used per $100 \mathrm{~g}$ of cucumber pickles tested.

WSP: water soluble pectin, PSP : $0.4 \%$ hexametaphosphate soluble pectin, HSP: $0.05 \mathrm{~N}$ hydrochloric acid soluble pectin, SSP: $0.05 \mathrm{~N}$ sodium hydroxide soluble pectin 


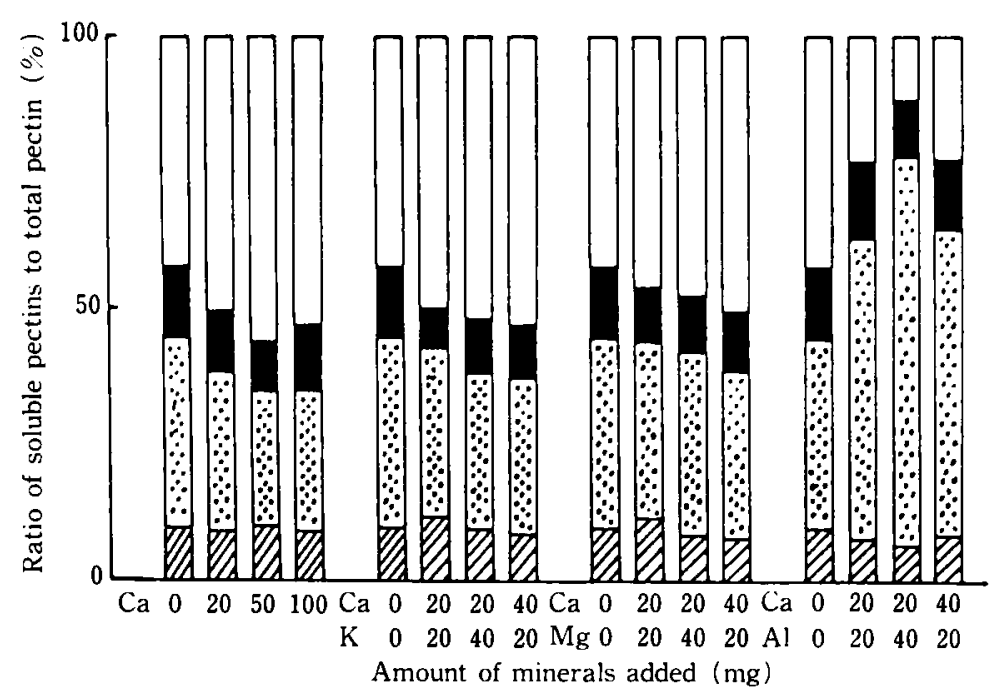

Fig. 7 Ratio of soluble pectins to total pectin in the alcohol insoluble substance pre pared from the center of cucumber pickles

Water soluble pectin

0.4\% Hexametaphosphate soluble pectin

$0.05 \mathrm{~N}$ Hydrochloric acid soluble pectin

$\square 0.05 \mathrm{~N}$ Sodium hydroxide soluble pectin

Each figure is the weight of minerals added per $100 \mathrm{~g}$ cucumber pickles tested.

である。これらの区では,一部マグネシウムによる影響 がみられるものの, カルシウムの添加量に伴って硬度は 增大を示した。またこれらの各区において硬度に関与 すると考えられているペクチン，すなわち，AIS 中の PSP と HSP についてみると, 対照区の PSP 5.5\%, HSP 2.1\%に対して，これらの区はそれぞれ 3.8〜5.4 $\%, 1.4 \sim 1.9 \%$ といずれも減少しているのが認められ た。一方, SSP は対照区の6.6\%に対してカルシウム 単用区では，カルシウム添加量 $20,50,100 \mathrm{mg}$ に対し て SSP はそれぞれ7.5，8.6，8.3\%であった。また， カルシウムーカリウムおよびカルシウムーマグネシウム併 用区においても同様に 7.5〜9.1\%を示しており，ま た，硬度の增大に伴って SSP む増加する傾向が認めら れた。

以上の結果から,キュウリピクルスにおける肉質の硬 さについては，無機成分としては添加量の增加に伴って 硬度が増大したカルシウムが最も硬度に関与しているむ のと考えられる。また，ペクチンとしては，WSP は当 然のこととして，沢奄漬等では果肉硬度に最む関与して いるぺクチンとしてあげられている PSP(4)は，カルシ ウム単用区, カルシウムーカリウムおよびカルシウムーマ
グネシウム併用区においては硬度の増大に伴って隇少し ている。これとは反対にカルシウムーアルミニウム併用 区では硬度の増大が認められないにもかかわらず PSP の顕著な増加を示していることからキュウリピクルス においては PSP の硬度に及ばす影䪤は極めて低いむの と思わ机る。一方, SSP は硬度の増大に伴って堌加する 傾向がみられ，キュウリピクルスの肉質の便さについて はSSPが最む関㐿が深いよらに思われる。しかし、この 違いは明らかでなく，今後検討を進めていく予定である。

\section{要約}

キュウリピクルスに無機成分を加え，果肉のテクスチ +ーやペクチンへの影響について検討した。

(1) カルシウム単用区ではカルシウム添加量に伴って 果肉硬度は増大した。カルシウムーカリウム, カルシウ ムーマグネシウム併用区はカルシウム単用区に比べて硬 度が増大することはなかった。カルシウムーアルミニウ ム併用区では，無機成分を加えないキェウリピクルスと 同じ硬度を示し，アルミニウムはカルシウム添加の効果 を抑制した。

(2) AIS 中のカルシウム量は，カルシウム単用区で 
は添加量の增加に伴って增加した。また，カルシウムー カリウム, カルシウムーマグネシウム併用区では，カル シウム単用区と同じカルシウム添加量であれば，ほぼ同 じ含量を示した。しかし，カルシウムーフルミニウム併 用区では他の区に比べて低い值を示した。

(3) AIS 中のペクチンは, WSP と HSP はいずれの 区においても非常に少なかった。しかし，PSPはいず れの区る高い值を示し，特にカルシウムーアルミニウム 并用区では影著であった。SSP はPSP に比ぺてカルシ ウムーフルミニウム併用区ではかなり低い值を示したが， その他の区では高い値を示した。

\section{文献}

1) 芥田三郎：日食工誌，32，43 (1976).

2) 满田 度：食品工業, 14, 28 (1971).

3) Buesher, R. W., Hudson, J. M. and Adams, J. R.: J. Food Sci., 44, 1786 (1976).

4) 小川敏男: 最新清物製造技術（食品研究社）, p.
207 (1967).

5) 川端晶子：調理科学， 15, 71 (1982).

6)作物分析法委員会編：栽培植物分析測定法（養賢 堂), p. 76 (1980).

7) 作物分析法委員会編：栽培植物分析測定法（蕞賢 堂), p. 146 (1980).

8) 桑原咗二・大塚啺茾・真部正敏：日本食品工業学 会第 30 回大会譳集, p. 33, 東大阪 (1983).

9) 真部正敏・坂根莘雄・梅谷隆之：面川大学農学部 学術報告, 26, 7 (1974).

10) Barbier, M. and Jhibault, J. F.: Phytochemistry, 21, 111 (1982).

11) МсСомв, E. A. and McCready, R. M.: Anal Chem., 24, 1630 (1952).

12）小田圭昭・富田芳雄：栄養と食糧, 32, 13(1979),

13）小西英子・㴊上倫子・岡本蜸一：栄養と食糧, 28, 44 (1975) .

14）金子害太郎 - 黒坂光江 - 前田安彦：日食工誌, 29, 611 (1981).

（昭和 59 年 12 月 3 日受理） 